\title{
Gereja Yang Berfokus Pada Gerakan Misioner
}

\author{
Hery Susanto 1$)^{*}$ \\ 1) Sekolah Tinggi Teologi Jemaat Kristus Indonesia \\ *)_Email: h.susanto@sttjki.ac.id.
}

Received: 24 Jan 2019 / Revised: 05 March 2019 / Accepted: 07 May 2019

\begin{abstract}
Abstrak
Gereja pada masa kini terus berkembang dan berwujud dalam berbagai format. Pada kenyataannya gereja-gereja cenderung membangun kekuasaannya sendiri dan kerajaannya. Dalam artikel ini, akan diuraikan tentang betapa pentingnya sebagai sebuah gereja untuk tetap berpusat kepada Kristus dan menyadari tanggungjawab utamanya adalah mewartakan Injil sebagai sebuah Missio Dei (misi dari Tuhan). Metode penulisan yang digunakan adalah meninjau melalui pendekatan sejarah gereja sebagaimana ditunjukkan dalam Alkitab, khususnya di dalam Kisah Para Rasul. Tantangan yang dihadapi gereja masa kini adalah bagaimana gereja tetap bekerja di tengah masyarakat post modern melalui misi yang kontekstual. Masyarakat memiliki keyakinannya masing-masing dan apa yang bisa diperbuat adalah menjadi bagian dari dunia dengan paradigma seperti Allah melihat yaitu untuk mendirikan Kerajaan-Nya di bumi seperti di surga. Kesimpulannya bahwa gereja seharusnya tidak hanya fokus pada hal-hal di dalam (internal) tapi juga tetap melakukan gerakan missioner ke seluruh dunia seperti yang diamanatkan oleh Tuhan Yesus.
\end{abstract}

Kata Kunci: gereja, Berpusat pada Kristus, Missio Dei, kontekstualisasi, misi

\section{Abstract}

Churches in this era has been developed and shaped in many forms. Obviously the churches tend to build their own authority and kingdom. In this article, describing about how important as church to be Christ centered and realize their main obligation to spread the Gospel as Missio 
Dei (mission from God). The method that been used is historical approach as shown in the scripture, specially the Book of Acts. The challenge that has been found recently is that the church should keep on working among people in post modern era through contextualization mission. People has their own beliefs and what we can do is becoming part of the world with new paradigm as God view to establish His Kingdom as in heaven and earth. The summary said that church should not focusing inside only but should keep doing outreach to all over the world. The church should be Christ centered and mission centered as living organism. The church is a movement that happen continually and progressive.

Keywords: church, Christ-centered, Missio Dei, contextualization, mission

\section{Pendahuluan}

Gereja sebagai satu tubuh Kristus memiliki sejarah panjang dalam pertumbuhannya. Gereja selalu beradaptasi dengan konteks masanya di dunia. Perubahan-perubahan model atau pola hidup gereja menunjukkan bahwa gereja bersifat dinamis dan hidup. Latar belakang masalah dari artikel ini adalah keberadaan gereja yang justru mengutamakan 'gerejagereja lokal' masing-masing. Gereja berusaha menarik orang untuk datang ke gerejanya sebagai indikator keberhasilan pelayanan gereja. Hal tersebut adalah sebuah ironi yang sangat kontras dengan apa yang Tuhan Yesus ajarkan di dalam Firman Tuhan.

Gereja perlu membuka mata hatinya untuk kembali melihat esensi dari keberadaan gereja adalah menjadi katalisator di dunia dan membawa terang kepada dunia yang gelap dengan berbagai sekularisasi dan world view yang berbeda. Sementara itu gereja menjadi alat-Nya untuk mewartakan Kabar Baik dan mendatangkan kerajaan Allah ke dalam dunia. Dalam hal ini berarti bahwa Kerajaan Allah adalah sebuah sistem pemerintahan yang mengakui Yesus Tuhan sebagai Raja dan pemerintahan dijalankan sesuai dengan Firman Tuhan. Gereja yang menyadari perbedaan paradigm ini akan melakukan gerakan karena dunia ini sedang sibuk dengan pergulatan masalah hidup pada saat ini. Tantangan bagi gereja untuk dapat menolong orang-orang yang di luar gereja melihat sebuah cara pandang yang ada di atasnya yaitu keberadaan Tuhan di dalam realita hidup.

Masalah selanjutnya adalah adanya kecenderungan gereja pada masa kini yang tidak terlibat aktif dalam penginjilan atau bermisi. Perkembangan 
gereja lebih banyak yang disebabkan oleh keturunan dan perpindahan anggota gereja satu ke gereja yang lain. Fokus gereja untuk bermisi hanya dibebankan kepada para misionaris atau pelayan-pelayan Tuhan secara khusus. Sesungguhnya amanat Tuhan Yesus berlaku untuk kita semua sebagai anggota jemaat dan memfungsikan gereja sebagai kesatuan tubuh Kristus yang bermisi perlu dioptimalkan.

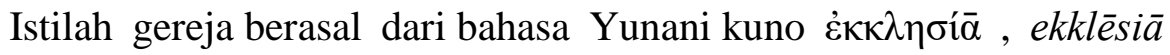
(bahasa Latin: ecclesia) artinya "jemaat, gereja", dan akhiran - $\lambda$ oyí, -logia, yang berarti "perkataan", "pengetahuan", atau "logika". Dalam dunia Yunani-Romawi, ekklesia digunakan untuk merujuk suatu pertemuan sah, atau disebut badan kepengurusan. Sejak awal pada zaman Pythagoras, kata ini mengandung makna lain yaitu komunitas dengan kepercayaan yang sama. Makna inilah yang dipakai dalam terjemahan bahasa Yunani untuk Alkitab Ibrani (disebut Septuaginta), dan kemudian digunakan pula oleh komunitas Kristen untuk merujuk pertemuan para orang percaya. ${ }^{1}$ Gereja adalah sekumpulan orang percaya yang berkumpul bersama untuk beribadah di dalam nama Yesus Kristus dengan tugas untuk membawa orang yang masih berada dalam gelap kepada terang Tuhan. Sebagaimana pembelaan rasul Paulus yang dengan berani menyatakan bahwa semua orang percaya memiliki tugas untuk menjadi pelayan dan saksi iman dan membawa keluar orang dari kuasa kegelapan kepada terang Tuhan dan dikuduskan (Kisah Para Rasul 26:16-18).

Menurut Boland, di dalam ilmu teologi, istilah gereja dibagi dalam istilah 'gereja yang kelihatan' dan 'gereja yang tidak kelihatan'. ${ }^{2}$ Gereja mulai fokus kepada segala kegiatan program di dalamnya supaya menjadi sebuah organisasi atau institusi yang terorganisir dengan kegiatan rutin seperti menyanyi, berdoa, kotbah dan memberi persembahan. Sementara itu "gereja yang tidak kelihatan" itu semakin kabur. Nuansa rohani memudar karena semua menjadi suatu kegiatan rutin yang dilakukan orang Kristen sebagai bagian dari kewajiban beribadah semata.

Pertanyaannya adalah apakah gereja-gereja Kristen pada masa kini masih selaras dengan spirit yang dimiliki oleh para rasul dalam Perjanjian

${ }^{1}$ F. Bauer, W. Danker, A Greek English Lexicon of the New Testament and other Early Christian Literature, third ed. (Chicago:University of Chicago Press, 2000), 195

2 Boland, BJ., Van Niftrik, Dogmatika Masa Kini (Jakarta: BPK. Gunung Mulia,2015), 352 
Baru di mana mereka berjuang bersama untuk membangun Kerajaan Allah. Boland juga mengatakan bahwa banyak gereja yang merayakan ulang tahun 'gerejanya' masing-masing sebagai ekspresi eklusifitas yang sangat berbeda dengan gerakan para rasul. Mereka tidak memusingkan gereja apa atau mana yang terpenting adalah jiwa-jiwa yang terselamatkan dan terpelihara dengan baik ${ }^{3}$.

\section{Metode Penelitian}

Penulisan artikel ini menggunakan metode penelitian kualitatif dengan penyelidikan literatur yang menguraikan tentang gereja. Pendekatan yang dilakukan adalah dengan meninjau sejarah pertumbuhan gereja mulamula sebagaimana ditulis di dalam Kisah Para Rasul. Bagaimana gerakan misioner gereja mula-mula dilakukan? Bagaimana sejarah pertumbuhan gereja mula-mula menunjukkan bahwa perkembangannya disebabkan oleh gerakan missioner? Apakah yang harus dilakukan oleh gereja masa kini agar spirit missioner tersebut dapat dikobarkan kembali?

Pembahasan masalah penelitian dimulai dengan gerakan misioner yang dilakukan oleh para rasul dan jemaat. Kemudian pada bagian selanjutnya dibahas tentang kehidupan gereja mula-mula yang mengedepankan kesatuan hati dan semangat untuk memberitakan Injil sesuai perintah dari Tuhan Yesus. Pada bagian ketiga, mengamati perkembangan gereja pada masa kini yang harus mengalami restorasi kembali kepada gerakan misioner.

\section{Pembahasan}

Gereja mengemban tugas Allah yang disebut sebagai Missio Dei. Allah menghendaki bahwa kerajaan Allah harus dinyatakan di bumi ini. Persoalan kerajaan Allah ini mengandung tiga pandangan yang berbeda. Menurut Kees De Jong, pandangan pertama menganut visi tradisional yang melihat bahwa gereja adalah kerajaan Allah dalam sejarah. Pendapat kedua mengatakan bahwa gereja bukan kerajaan Allah melainkan gereja adalah awal mula dan hasil pertama dari Kerajaan Allah yang akan disempurnakan

\footnotetext{
${ }^{3}$ Boland, 353
} 
oleh Allah sendiri di masa depan. Oleh sebab itu gereja harus terus membangun keadilan, persaudaraan dan kebebasan dalam sejarah. ${ }^{4}$

Pendapat dari para teolog Asia menganggap kerajaan Allah secara sederhana sebagai lingkungan kehadiran dan kegiatan Allah. Kerajaan Allah mencakup keseluruhan dalam sejarah manusia. Kerajaan Allah baik historis maupun eskatologis sedang dalam proses dibangun oleh manusia. Termasuk agama-agama lain, walaupun gereja mempunyai hubungan khusus dengan kerajaan Allah. Sebagai suatu komunitas manusiawi di mana ada kebebasan, persaudaraan, keadilan dan cinta kasih, fokus utamanya adalah bukan hal religius tetapi 'sekuler'. Bahkan orang yang tidak memeluk agama apapun, tetapi mempunyai kehendak baik, dapat memberi sumbangan pada pembangunan Kerajaan Allah, dan secara itu merupakan juga warga-wargaNya. $^{5}$

Pendapat ini cukup mengejutkan karena gereja sebagai tubuh Kristus justru kurang memahami hal ini di dalam konsep bermisi. Gereja memandang bahwa misi berarti membawa orang untuk masuk ke dalam 'gereja mereka'. Pada kenyataannya, konsep Missio Dei seharusnya merangkul semua umat Tuhan apapun agamanya. Dalam pengertian ini bukan dimaksudkan sekularisasi mengesampingkan religiusitas, atau keyakinan yang konservatif dilawankan dengan pluralisme, tetapi melihat bahwa Kerajaan Allah selalu bersifat inklusif bagi siapapun juga. Ketika mereka berani mengubah paradigma dunia tentang apa yang mereka sebut 'agama' yang justru membatasi dan menjadi sekat-sekat, maka Allah hadir menyempurnakannya sehingga semua orang akan datang kepada Tuhan yang hidup sebagai Raja yang kekal.

Konteks kehidupan beragama di Indonesia cukup unik karena Pancasila menjadikan payung kesatuan dalam keberagaman. Mengutip perkataan Woi Bule :

"Isu paling kuat dalam konteks keberagamanan agama adalah menguatnya identitas keagamaan di ruang publik. Isu ini dapat dipetakan sebagai berikut: pertama, isu terkait kebijakan public yakni masalah produk Undang-undang yang mempolarisasi kelompok

\footnotetext{
${ }^{4}$ Kees De Jong, "Misiologi dari Perspektif Teologi Kontekstual” Gema Teologi, sac.ukdw.ac.id. 2007; 56

${ }^{5}$ Michael Amaladoss, Mission in Asia: A Reflection on Ecclesia in Asia (New York: Orbis Books, 2012), 28
} 
keagamaan di tingkat daerah dengan perda-perda yang diskriminatif. Kedua, terorisme atas nama agama. Ketiga, konflik komunal antar komunitas agama. Keempat, konflik antar agama dalam kasus spesifik yaitu penodaan agama dan kesulitan membangun rumah ibadah."

Kondisi ini dapat dipandang oleh gereja sebagai suatu keadaan yang menyulitkan atau tidak menguntungkan gereja. Namun jika menelusuri sejarah gereja atau jemaat mula-mula sebagaimana sudah diuraikan di atas, gereja tersebut justru bertumbuh dan berkembang dalam situasi yang serba tidak menguntungkan. Tentu saja pemahaman kita mengenai gereja harus diberi kerangka yang luas sehingga tidak hanya sekedar memperluas tembok gereja masing-masing melainkan sungguh-sungguh menjadi bagian dari pekerjaan kerajaan Allah yang dinyatakan di dunia.

Gereja sebagai kumpulan orang-orang percaya harus tetap mengarahkan setiap program dan pemikirannya sesuai dengan apa yang Kristus kehendaki. Konsekuensi logisnya adalah gereja harus mengarahkan hati dan pikiran sesuai apa yang Kristus kehendaki yaitu menjadi saksi kebenaran dan mengajak orang lain untuk dapat meneladani apa yang Yesus ajarkan.

Gereja atau kumpulan orang-orang percaya harus kembali kepada jati dirinya sebagai kumpulan orang-orang yang dipersatukan oleh Kristus, bukan diikat oleh persoalan hidup masing-masing sehingga berkumpul untuk mendapatkan pemuasan keinginan dan jalan keluar dari masalah. William Vun mengatakan bahwa gereja Tuhan bukan hanya sekedar perkumpulan sejumlah orang percaya dan menjadikannya sebatas kegiatan social semata.

"Memang tidak salah bagi gereja untuk menolong orang-orang yang berkekurangan dan tidak berdaya. Gereja harus melakukan hal itu, tetapi tidak membatasi gereja hanya pada pekerjaan-pekerjaan amal dan menyebutnya sebagai sebuah pelayanan. Gereja Tuhan melebihi dari sekedar kegiatan amal, proyek pendidikan, misi darurat, dan sebagainya... Gereja Tuhan lebih besar dari semua itu."7

${ }^{6}$ Yosep Aurelius Woi Bule, “ Revolusi Mental dengan Membangun Karakter Cinta Pluralitas", Atma Reksa, Jurnal Pastoral dan Kateketik, -jurnal.stiparende ac.id, 2017;18

${ }^{7}$ William Vun. 2010. Who is Building Whose Church? (Jakarta: Nafiri Gabriel, 2010), 36 
Gereja harus mengarah kepada satu komando yang sama dari Kristus. Apapun persoalan hidup, mereka harus tetap bersatu dalam perintah Sang Tuan yaitu Yesus Kristus sendiri. Sebagai anggota tubuh Kristus tentunya berani mengalahkan kepentingan pribadi masing-masing demi kesatuan dan berfungsinya tubuh Kristus secara sehat.

Kristus mengatakan kepada murid-murid-Nya bahwa mereka akan melakukan pekerjaan-pekerjaan yang lebih besar dari pada yang pernah Dia lakukan (Yohanes 14:12). Syaratnya bahwa mereka harus percaya kepadaNya. Dan di dalam perkembangan sejarah, semua perkataan Yesus terbukti bahwa para murid (disciples) tersebut menjadi para rasul (apostolos) yang dengan sungguh berani menjadi saksi Kristus di mana-mana bahkan sampai kepada orang-orang non Yahudi di tempat-tempat yang jauh. Kekuatan mereka terbangun karena persekutuan mereka (eklesia) difokuskan kepada gerakan misi dan mengumpulkan sebanyak-banyaknya orang percaya dan tidak membatasi diri pada tembok-tembok gereja. Mereka memahami dan melakukan perintah Tuhan Yesus dengan pimpinan Roh Kudus tanpa mengenal lelah.

\section{Gerakan Misioner Yang Dinamis}

Gereja-gereja mula-mula tidak pernah berhenti bergerak dalam bermisi. Pada hari Pentakosta, kurang lebih 120 orang percaya berkumpul di Yerusalem dan Roh Kudus turun ke atas mereka sehingga mereka berbahasa lidah (glossolalia). Hal ini sangat mengagumkan karena bahasa tersebut bisa dimengerti oleh umat Tuhan yang hadir dalam acara tersebut yang berasal dari daerah jauh, wilayah Roma barat dan Partia di sebelah timur atau sekarang Iran dan Afganistan. Kemudian Petrus berkotbah dan 3000 orang menerima firman itu dan mereka dibaptis. Misi Rasul Paulus yang menjangkau orang-orang non Yahudi melintasi batas Yerusalem dan Antiokhia sebagai tempat mula-mula gereja itu berdiri. "As the church grew, so the opposition escalated. Warnings, arrests, and beatings culminated in the stoning of Stephen, the first Christian martyr, which led to the scattering of the church throughout Judea and Samaria."

\footnotetext{
${ }^{8}$ Paul Lawrence, The IVP Concise Atlas of Bible History (Illinois: Inter Varsity Press, 2004), 145
} 
Semakin gereja berkembang, teror dan ancaman juga meningkat. Hal ini tidak menghentikan semangat gereja-gereja atau jemaat untuk terus bergerak. Bahkan mereka dianggap sebagai ancaman bagi pemerintah Romawi karena mengubah tatanan sosial dan dianggap meresahkan komunitas religius Yahudi. ${ }^{9}$

Para tokoh agama Yahudi yang sudah menyalibkan Yesus juga terusik karena pengaruh yang sangat besar dari Yesus dianggap menurunkan popularitas mereka dalam mempertahankan identitas mereka sebagai orang Yahudi yang memegang kuat hukum Taurat. Para jemaat pergi menyebar dan meninggalkan zona nyaman mereka untuk bisa bergerak lebih aman. Banyak di antara merekapun akhirnya menjadi martyr karena Injil. Gereja tidak hanya tempat kumpul atau mencari komunitas saja namun justru seperti home base bagi mereka untuk bergerak keluar, mencari komunitas lain untuk dijangkau yang siap untuk mendengar dan menerima Injil. Mereka saling terkoneksi dalam keadaan yang kurang kondusif untuk bertahan di satu tempat saja. Dinamika gereja sangat aktif dan seperti virus positif yang sedang menyebar tanpa bisa dihentikan. Pusat mereka adalah Kristus, bukan gereja setempat. Semua mengambil peran dalam gerakan misioner ini sehingga banyak bangsa mendengar Injil dan menerima, menyerahkan diri untuk dibaptis.

Para jemaat menyebar ke daerah Mediteranea timur. Sebagian jemaat di Antiokhia mulai bercerita kepada orang-orang non Yahudi tentang Yesus dan banyak yang menjadi percaya. Gereja Yerusalem mengutus Barnabas untuk menyelidikinya. Dia mengajak Saulus dari Tarsus dan mengajar masyarakat di sana selama satu tahun. Di situlah awal mulanya mereka disebut sebagai orang Kristen. Saul dan Barnabas kemudian mengumpulkan dana untuk pelayanan gereja di wilayah Yudea.

Perjalanan para rasul bukanlah hal yang mudah karena mereka harus berjalan kaki atau naik kuda bagi yang mampu. Perjalanan kaki sejauh 500 km ditempuh dalam waktu 15 hari. Pada tahun 333 M, orang-orang Kristen harus bepergian dari Bordeaux ke Yerusalem sejauh $5000 \mathrm{~km}$ dan memerlukan waktu 170 hari. Pada lain waktu, perjalanan misi melalui laut

\footnotetext{
${ }^{9}$ P. Schaff, History of the Christian Church in The Middle Ages (Grand Rapid: Eerdmans Publishing Company, 1949), 43
} 
memakan waktu 3 hari untuk jarak $500 \mathrm{~km} .{ }^{10}$ Para rasul harus memberitakan Injil kepada orang-orang yang masih terikat dengan budayabudaya penyembahan kepada dewa-dewa. Gereja melakukan tugas pemberitaan Injil dengan penuh semangat dalam rangka menjalankan misi Tuhan bagi dunia.

Sebagaimana Abraham dipanggil keluar dari dunia orang kafir (Kejadian 12:1), demikian pula gereja dipanggil keluar dari bangsa-bangsa, "keluar dari kegelapan kepada terang-Nya yang ajaib (1 Petrus 2:9; Kolose 1:13). Jadi demikian pula gereja timbul sebagai hasil pekerjaan Roh Kudus, yang dipakai sebagai alat Roh Kudus untuk memperhadapkan orang-orang kepada Kristus.

Kisah Rasul 2 mencatat bahwa Petrus mendasarkan kotbahnya di atas Kitab Suci. Gereja menjalankan dua sakramen utama yaitu baptisan kudus (Kis.2:38) dan Perjamuan Kudus (Kis. 2:42). Selain itu jemaat selalu giat dalam berdoa (2:42) dan melakukan pekerjaan sosial yang selalu peduli kepada sesama (2:45). Suatu sistem yang dibangun bahwa gereja adalah umat Tuhan yang semestinya menjadi kesaksian tentang Yesus sehingga orang-orang di luar gereja akan melihat dan menerima Kristus sebagai Tuhan dan juruselamat mereka.

Jika ditarik ke dunia Perjanjian Lama, Allah memilih bangsa Israel agar bangsa-lain menjadi tahu dan mengenal siapa Allah itu dan mau hidup dalam pimpinan Allah. Namun bangsa Israel gagal menjadi saksi yang baik sehingga justru karena perbuatan mereka membuat banyak bangsa merasa antipati dan meninggalkan Allah. Sementara itu bangsa Israel sendiri merasa menjadi bangsa pilihan khusus dan menjadi sangat ekslusif dalam ritual dan tradisi mereka. Bangunan tembok mereka membatasi orang di luar untuk masuk ke dalam tradisi mereka, bahkan untuk mengenal Allah mereka yang disebut YAHWEH.

Perjanjian Baru mengubah pola itu. Allah sendiri yang datang menjadi manusia melalui Yesus Kristus. Dia menjadi teladan sekaligus menjadi korban buat manusia yang berdosa. Yesus menjalankan misi Allah dengan segenap hati dan Dia memberikan janji kepada para rasul bahwa Roh Kudus akan menolong mereka menjadi saksi melalui pemberitaan Injil.

${ }^{10}$ Paul Lawrence, 148 
Gerakan gereja menjadi sentripetal (bergerak keluar). Hal ini tidak mengurangi pentingnya unsur-unsur kunci dalam gereja.

Unsur-unsur kunci yang dimaksudkan adalah:(1) pemberitaan Injil tentang Yesus Kristus, sesuai dengan kesaksian Alkitab, baik ke dalam maupun keluar; (2) melakukan sakramen-sakramen sebagai bentuk 'pemberitaan dalam bentuk yang kelihatan; (3) doa dan syafaat ; (4) pekerjaan sosial kepada lingkungan dan anggota jemaat; (5) penggembalaan (pemeliharaan jiwa) serta siasat/ disiplin (pengawasan) atas hidup dan kepercayaan anggota-anggota gereja, untuk menarik jemaat kepada pemberitaan Firman Allah serta mengikatnya kepada Firman itu.

Dari kelima unsur tersebut, gereja tetap mengarahkan diri kepada kesaksian tentang Yesus Kristus yang dibangun atas dasar kesaksian para rasul tentang Yesus Kristus. Ketika gereja lebih menempatkan porsi pemberitaan kepada apa yang akan diperoleh lebih daripada porsi tentang Yesus Kristus yang mengerjakan kehendak Bapa, maka gereja itu sedang bergerak meleset dari apa yang semestinya. Gereja yang melalaikan pemberitaan Injil, tidak berhak lagi disebut 'gereja' (Kis.1:8). Boland mengatakan bahwa mustahil jika sebuah gereja merupakan benar-benar sebuah gereja jika dia hanya berusaha "membereskan dulu" soal-soal internal baru akan menjalankan misi, karena justru oleh tugas itu gereja hadir di dalam dunia ini. Jadi dengan demikian setiap jemaat yang percaya kepada Tuhan Yesus akan secara sukarela melibatkan diri dalam gerakan bermisi, mewartakan kesaksian tentang Yesus Kristus.

Yesus Kristus datang ke dunia menjadi Tuhan bagi semua orang yang percaya sehingga semuanya tanpa terkecuali harus terlibat di dalamnya, bukan sekedar sebagai penonton. Gerakan bermisi adalah terkoordinasi oleh seluruh anggota gereja, bukan sekedar para pemimpinnya saja. Karena di dalam 1 Petrus 2:9 mengatakan bahwa, "kamulah bangsa yang terpilih, imamat yang rajani, bangsa yang kudus, umat kepunyaan Allah sendiri, supaya kamu memberitakan perbuatan-perbuatanyang besar dari Dia yang telah memanggil kamu keluar dari kegelapan kepada terang-Nya yang ajaib." Pengertiannya adalah ditujukan kepada gereja secara menyeluruh, semua jemaat termasuk di dalamnya. Ketika jemaat sebagai anggota tubuh Kristus tidak terlibat dalam gerakan misi berarti ada sesuatu yang salah di dalam pengelolaan gereja tersebut. Para pemimpin gereja, gembala sidang dan para majelis atau penatua harus memberikan teladan dan melakukan 
tugas ini bersama dengan jemaat dengan tujuan bukan untuk memperluas gereja lokal tetapi dalam rangka menjalankan misi yang diperintahkan oleh Tuhan kepada mereka sebagai para murid Kristus. Satu catatan pentingnya adalah bahwa di dalam pelaksanaan misi ini harus dibawa dalam sebuah sikap atau motif yang benar, yaitu menjalankan misi Tuhan. Bukan menanyakan apa yang akan didapat tetapi apa yang bisa dilakukan untuk Tuhan sebagai wujud pelaksanaan Amanat Agung.

Gereja yang berteologi kuat akan menyadari bahwa hadirnya gereja adalah didorong oleh sebuah visi yang kuat menjangkau orang-orang yang belum dijangkau atau belum mendengar Injil. Nafas gerakan gereja yang membuatnya tetap hidup adalah dengan tetap melakukan misi dan berani keluar dari kerangka tembok gereja lokal. Ketika jemaat bergerak untuk bermisi maka gereja memberikan back up melalui doa dan dukungan secara moral dan finansial sebagaimana Kisah Para Rasul melakukannya dengan gereja mula-mula.

\section{Sejarah Pertumbuhan Jemaat Mula-Mula}

Para ahli sejarah mencatat bahwa kurang lebih sepersepuluh populasi orang Roma pada tahun 300 M telah menjadi Kristen (atau kurang lebih 57,5 juta orang dari keseluruhan populasi 60 juta orang). Kemudian situasi menjadi berubah ketika Kaisar Konstantin ikut bertobat. Pertumbuhan kekristenan dari sekumpulan orang percaya berjumlah 120 orang pada tahun 30M (Kis. 1:14-16) bertambah menjadi 6 juta orang setelah 270 tahun kemudian. ${ }^{11}$

Kondisi pertumbuhan gereja semacam ini merupakan hal yang luar biasa. Pertumbuhan ini terjadi bukan dalam kondisi tempat yang aman, menetap, ideal untuk anak-anak. Justru ledakan ini terjadi dalam kesukaran besar karena semenjak Yesus mati, maka mereka yang mengaku percaya kepada-Nya malah dikejar-kejar untuk dibunuh. Orang Kristen percaya bahwa di balik peristiwa yang menyesakkan itu, tangan Tuhan bekerja di balik pertumbuhan gereja dan pertobatan terjadi karena karya Roh Kudus. Di dalam konteks historis ini tidak ada bukti bahwa ada satu strategi misionaris yang paling efektif dalam ledakan ini karena semua berasal dari

${ }^{11}$ Ian J.Shaw, Christianity the Biography. (London: Inter Varsity Press, 2016), 28 
Roh Kudus yang membuat semua terjadi begitu saja. Gereja-gereja menjadi begitu bersemangat untuk melakukan pewartaan Injil ke mana-mana.

Agama-agama dalam dunia kuno tidak mengenal istilah misi seperti yang dilakukan rasul Paulus. Perkembangan agama-agama dalam budaya Timur Dekat kuno cenderung mengikuti pola invasi dari para pasukan militer. Para penginjil waktu itu hanya bersenjatakan keberanian untuk menyampaikan pesan tentang pertobatan dan iman kepada Yesus sang Juruselamat dan dampaknya lebih luas dan bertahan lebih lama. Biasanya mereka mengunjungi sinagog setempat, sebagai tempat berkumpulnya orang-orang Yahudi. Ketika mereka disambut, terjadilah komunikasi mereka dengan para rabi Yahudi dan menjadi kesempatan bagi mereka untuk menyampaikan pesan Guru mereka. Para penginjil ini berjumpa dengan orang-orang yang merindukan adanya tokoh yang menyelamatkan mereka (walaupun ada kecenderungan maknanya politis bukan keselamatan rohani). Situasi diaspora menguntungkan kegiatan penginjilan ini karena mereka bisa menjangkau daerah yang jauh lebih luas daripada sekedar Yerusalem saja.

Pada mulanya kekristenan berlindung di bawah payung tradisi Yahudi dan perlindungan resmi dari orang Yahudi dari kekuasaan Romawi untuk menjaga perdamaian di Palestina. Setiap kali Injil menghadapi rintangan secara politis, mereka juga mulai melintasi budaya yang ada. Tapi ternyata pesan Injil dapat menerobos itu semua sehingga banyak orang menerima dan percaya Injil tersebut dan mengabaikan perbedaan ras, budaya, atau latar belakang politik.

Selain di sinagog, para penginjil juga memberitakan Injil di jalanjalan, pasar, bahkan rumah pribadi. Media kunci dalam berkomunikasi adalah melalui kata-kata verbal, kadang melalui pesan khotbah, atau juga melalui percakapan biasa dan dialog. Salah satu dampak besar dari spirit mereka menginjil adalah keberanian mereka yang tidak mengenal takut untuk mati bagi Kristus. Pada awalnya jemaat Kristen menunjukkan tingkat komitmen yang tinggi terhadap Amanat Agung Yesus Kristus yang tidak ditemukan dalam abad-abad berikutnya. Mereka berjuang untuk terus mengabarkan Firman Tuhan dalam tangis dan penderitaan karena menjadi para pengungsi, diasingkan dan dipenjara, dan bahkan menjadi saksi sampai harus mengorbankan nyawa sebagai martir. Ian Shaw menyatakan bahwa: "The Antioch model only become widespread in the middle of the second 
century. By the third century the monarchial view of leadership had prevailed and a hierarchical pattern was established." 12

Rupanya pada abad ketiga telah terjadi pergeseran dalam gerakan para rasul yang siap untuk mati demi Injil diganti dengan model hirarkhial yang membatasi gereja dalam hal pengajaran Injil oleh tokoh-tokoh yang dianggap lebih kompeten melakukan tugas tersebut. Akibatnya dalam perkembangan sejarah gereja muncullah berbagai aliran denominasi yang membuat gereja-gereja disebut dengan istilah gereja-gereja main stream dan gereja-gereja pertobatan.

Menurut Jan Aritonang: "Masing-masing aliran lahir dari latar belakang, pergumulan dan konteks tertentu. Dengan kata lain, semua aliran merupakan produk sejarah pada masa tertentu. Karena itu masing-masing mempunyai alasan yang sah bagi kemunculan dan kehadirannya."13

Berdasarkan pendapat Jan Aritonang tersebut nampak bahwa dalam setiap periode sejarah tertentu, gereja terus mengalami perkembangan secara jumlah maupun gerakannya yang semakin bervariasi di dalam pengelolaannya. Menurut Ciprianus, sakramen Kristen dan para pelayannya memakai pola korban dalam Perjanjian Lama dan kategori keimaman. Dia percaya bahwa hanya ada satu gereja sebagai satu keyakinan keselamatan. Tak ada satu orangpun yang memiliki Allah sebagai Bapa tapi tidak mengakui gereja sebagai ibunya. Artinya bahwa gereja sebagai mempelai Kristus harus menjadi satu hal yang utuh sebagai satu keluarga. Perbedaan yang ada hanya terletak pada praktek iman pribadi masing-masing.

Salah satu petikan dalam sejarah kekristenan pada masa pemerintahan Paus Bonifatius VIII (1294-1303). Ia mengeluarkan sebuah ketetapan yang disebut Unam Sactam. Ia menuntut kemahakuasaan menyeluruh atas dunia ini sebagai wakil Kristus mencakup soal rohani maupun politik ${ }^{14}$. Mardiatmadja menyebutkan istilah" gereja sebagai imperium" yang mengurusi soal keagamaan dan kenegaraan. Hal ini menjadikan gereja terlalu menekankan kepada "gereja yang kelihatan' atau berstruktur teratur. Sebagai organisasi dengan pemimpin manusia, Paus

\footnotetext{
${ }^{12}$ Ian J.Shaw, Christianity the Biography. (London: Inter Varsity Press, 2016), 32

${ }^{13}$ Jan Aritonang, Berbagai Aliran di Dalam dan di Sekitar Gereja (Jakarta: BPK. Gunung Mulia, 2012), 6

${ }^{14}$ P. Schaff, History of the Christian Church in The Middle Ages (Grand Rapids: Eerdmans Publishing Company, 1949), 75
} 
sebagai wakil Kristus. Akibatnya gereja sebagai institusi lebih utama dari gereja sebagai organisme. Dalam sebuah tulisan di jurnal Waskita, Agustinus menyatakan bahwa: Gereja menjadi satu-satunya lembaga atau bahtera keselamatan dengan tiga fungsi: 1) menyebarkan iman yang benar dengan jalan memberitakan Firman; 2) memelihara kesucian dengan jalan sakramen; 3) mengorganisasikan warganya dengan hukum gerejawi yang ketat. $^{15}$

Ajaran Kristen sarat dengan ajaran kasih dan kebaikan yang diteladankan oleh Tuhan Yesus sendiri dan itu berarti gereja seharusnya tidak terjebak dalam suatu institusi atau organisasi semata melainkan memiliki standar moral yang berbeda dengan orang beragama pada umumnya. Kebutuhan standar moral yang tinggi ditekankan dalam tulisantulisan Kristen pada masa itu. Didakhe (tulisan-tulisan ajaran) berbicara tentang kasih kepada Allah, kepada sesama, dan memelihara Sepuluh Perintah Allah sebagai pedoman hidup. Ajaran yang benar dan pelaksanaan yang benar berjalan seiring. Kekristenan berada di dalam situasi yang tidak semuanya sempurna. Dunia di sekitar gereja berada dalam situasi yang korup secara moral, finansial, suap menjadi hal yang biasa. Tanggung jawab gereja untuk tetap berada dalam standar moral yang tinggi menjadikan sebuah ironi dan sindiran sebagaimana ditulis dalam surat kepada Dionitus, “... mereka mengasihi semua orang, dan dianiaya oleh semua... mereka miskin, tapi justru memperkaya orang lain, mereka kekurangan segalanya, tetapi mereka terikat dalam segalanya... mereka dilecehkan tetapi sekaligus memberkati."

Di dalam jemaat, budak diperlakukan setara secara rohani dengan mereka yang merdeka atau bebas. Hal ini menarik perhatian mereka untuk memilih menjadi orang Kristen. Di dalam masyarakat Romawi wanita mendapatkan status legal lebih luas di banding Yudaisme, sedangkan di dalam ajaran Kekristenan kesetaraan antara wanita dan laki-laki menjadi jantung dari Injil yang membuat sesuatu yang berbeda susunannya. Buktinya di dalam Perjanjian Baru, banyak dikisahkan peran tokoh-tokoh wanita di dalam jemaat mula-mula. Menurut William Kurz:

${ }^{15}$ Agustinus M. Batlajery, “ Konteks yang Mempengaruhi Eklesiologi Calvin”, Waskita: Jurnal Studi Agama dan Masyarakat. Vol. 2, No.1, April 2014; 18 
"Seperti Murid yang Terkasih, kita harus menyadari bahwa Yesus mengasihi mereka secara mendalam dan menyatakan rahasiarahasia-Nya kepada mereka. Seperti Murid yang Terkasih itu, kita juga dipercayakan kepada ibu Yesus (baik Maria maupun gereja), dan ibu-Nya kepada mereka. Seperti Murid yang Terkasih itu mereka tahu dan harus menyaksikan darah dan air yang mengalir dari Yesus yang disalib itu, untuk mempercayai bahwa Ia sungguhsungguh telah bangkit, untuk memandang Yesus yang bangkit itu dari perbuatan-perbuatan-Nya yang ajaib di antara komunitas murid dan gereja, untuk tinggal hidup sampai Yesus datang kembali, dan untuk mengemban kesaksian yang benar tentang kabar baik mengenai Yesus." 16

Jadi tugas gereja adalah membagikan kesaksian tentang Yesus tanpa kecuali. Siapapun yang bergabung dalam gereja baik itu laki-laki atau wanita, kaya atau miskin, semua memiliki tugas atau kewajiban yang sama karena perintah Yesus sendiri yang mempercayakan murid-murid-Nya kepada ibu-Nya dan sebaliknya Maria dipercayakan kepada murid-muridNya. Gereja mempertahankan kebenaran di tengah ketidakbenaran sehingga menjadi tantangan tersendiri bagi orang-orang masa kini untuk dapat mewujudkannya. Kesaksian tentang Kristus yang menyatukan murid-murid Tuhan Yesus dengan Maria ibu-Nya dalam sebuah ikatan 'keluarga' dengan dasar kasih. Kedekatan hubungan dengan Yesus ini menjadikan gerakan misioner sebagai sebuah kesadaran dan bukan keterpaksaan karena perintah. Rasa kasih merupakan kekuatan karena kepedulian kepada sesama agar diselamatkan dan menerima Kristus menjadi pesan utamanya.

\section{Restorasi Gereja Kepada Gerakan Misi}

Istilah restorasi berasal dari akar kata re-store berarti mengembalikan kepada keadaan semula. Ketika gereja dikembalikan kepada keadaan semula, ini berarti bahwa esensi gereja dikembalikan kepada kehendak Tuhan terbentuknya gereja sebagai sekumpulan orang percaya yang dikumpulkan untuk melakukan Amanat Agung.

${ }^{16}$ Michael H. Crosby, Apakah Engkau Mengasihi Aku? (Jakarta: BPK Gunung Mulia, 2000), 27 
Gereja bukan lagi sebuah institusi yang diam atau property saja tetapi sebuah movement. Gereja harus selalu bergerak dan terus menyelaraskan langkah mengikuti alur kehendak Tuhan mengenalkan Yesus kepada seluruh dunia. Gereja yang merupakan gerakan ini akan menjadi sebuah sistem yang tidak bisa dihentikan dan terus berkembang ke segala arah untuk membawa kemuliaan bagi Allah.

Problemnya adalah ketika gereja pada masa kini lebih menekankan tentang teologi yang bersifat egosentris dan tidak mengarah kepada tugas utama jemaat untuk ikut dalam pemberitaan injil secara seimbang. Akibatnya jemaat melupakan tugas utamanya untuk menjadi umat yang bekerja giat bersama umat percaya lainnya menceritakan tentang Yesus Kristus yang bersedia mati buat pengampunan dosa dan kebangkitan-Nya menunjukkan bahwa Dia telah mengalahkan maut. Tujuan itu semua adalah untuk memulihkan hubungan yang rusak oleh dosa sehingga manusia kembali dipulihkan menjadi ciptaan yang segambar dan serupa dengan Allah.

Hery Susanto dalam salah satu tulisannya dalam Jurnal SIAP ${ }^{17}$ mengatakan bahwa kesatuan semua orang percaya menjadi sulit diwujudkan tapi harus diupayakan karena ada tiga alasan yang mendasarinya:

1. Mereka percaya bahwa penginjilan dunia telah mulai dicemari oleh terbagi-baginya gereja dalam kelompok-kelompok masing-masing.

2. Mereka percaya bahwa pembagian ini berlawanan dengan kehendak Allah dan model denominasi harus diakhiri.

3. Mereka percaya bahwa untuk menyatukan semua orang percaya dengan satu tujuan adalah hanya bisa dilakukan dengan mengesampingkan tradisi dan kredo yang memecah belah dan kembali pada apa yang disebut sebagai 'kekristenan primitif'.

Gerakan restorasi diperlukan untuk mengembalikan spirit gereja yang berfokus kepada misi penyelamatan bagi dunia. Gereja tanpa tembok menjadi wadah bagi jemaat untuk saling menguatkan dan inklusif untuk menerima siapapun yang mau belajar dari Firman Tuhan dan menjadi saksi bagi Kristus. Istilah denominasi yang merupakan ciri dari setiap gereja tidak harus menjadi pemecah belah, sebaliknya digunakan dengan hikmat Tuhan

\footnotetext{
${ }^{17}$ Hery Susanto, "Penemuan Jati Diri Gereja Jemaat Kristus pada Abad yang Baru", Jurnal SIAP Vol.5, no. 1, 2016; 36
} 
yang berarti didasari oleh rasa takut akan Tuhan sehingga menolong orangorang sesuai konteks di mana dan kapan mereka berada dalam suatu situasi secara khusus. Misalnya di dalam gereja karismatik akan menggunakan karunianya untuk lebih mengandalkan Roh Kudus sehingga mendapat keberanian untuk mengabarkan Injil kepada semua orang dengan pimpinan Roh Kudus. Gereja beraliran presbiterian dengan kekuatan organisasi yang terstruktur rapi dapat menggerakkan umatnya untuk terlibat dalam pelajaran teologis dan Firman Tuhan sehingga mereka terlibat di dalam pemahaman teologis yang benar dan kuat. Jika pemahaman dan penghayatan iman mereka didasarkan teologi yang kuat maka akan sangat berpeluang bahwa mereka bisa terlibat dalam gerakan misi yang lebih aktif lagi. Bagi gerejagereja yang menekankan eskatologi juga mempersiapkan kedatangan Kristus kedua kali dengan lebih giat melakukan penginjilan sebagaimana diajarkan bahwa Kristus akan datang kembali setelah seluruh bangsa mendengarkan Injil. Jadi muaranya tetap sama yaitu pengabaran Injil.

Pengabaran Injil merupakan tugas utama yang Tuhan inginkan dari berdirinya jemaat atau gereja. Namun ada hal yang harus diwaspadai adalah ketika kegiatan ini menjadikan para pelakunya menyamakan diri mereka dengan rasul pada jaman gereja mula-mula. Mike Shipman mengatakan:

"Bahaya terbesar dari penekanan kerasulan masa kini adalah apabila orang-orang menyatakan dirinya "rasul" dalam arti kerasulan otoritatif abad pertama. Sebaliknya, rasul masa kini adalah orangorang yang memimpin usaha memuridkan seluruh dunia. Otoritas mereka berdasar kepada ketaatan mereka kepada Amanat Agung dan kerelaan mereka menaati amanat tersebut dengan mengajar setiap generasi baru orang percaya untuk dengan segera menaati Amanat Agung sebagai rekan imam 100\%. Peran kerasulan adalah menjangkau, membaptis, melengkapi dan memberdayakan, artinya memimpin orang-orang percaya kepada iman, dan kemudian memimpin mereka memuridkan dunia mereka." 18

Perbedaan dalam setiap ajaran gereja tidak akan menjadi persoalan jika semua menyadari satu visi yang sama berkaitan dengan pemberitaan Injil, meskipun cara dan metodenya bisa bermacam-macam. Semua akan turut ambil bagian dalam tugas besar ini karena Tuhan menghendakinya.

${ }^{18}$ Mike Shipman, Kepemimpinan Kerasulan (Bandung: Dian Cipta, 2017), 20 
Otoritas kerasulan pada abad pertama yang dipicu oleh peristiwa pencurahan Roh Kudus tidak terulang kepada gereja masa kini, namun gerakan misioner masa kini terus berkembang dalam bentuk-bentuk pemuridan yang menjangkau orang-orang yang belum percaya dan membimbing mereka secara kontinyu agar iman percaya kepada Kristus bertumbuh.

Menurut Makmur Halim, landasan teologisnya adalah:

"Pendekatan dan Allah dalam sejarah umat Israel, baik secara umum maupun secara khusus, diterima melalui "cultural channels", hal ini kontras dengan "direct revelation atau direct experience". Gereja ditantang untuk "back to the Bible" yakni meneladani apa yang telah diperbuat oleh Allah dalam pendekatan dan pernyataan Allah dalam sejarah. Metode ini merupakan suatu contoh pendekatan yang aktual, relevan dan up to date bagi perkembangan gereja masa kini." 19

Jadi yang dimaksudkan di sini adalah kemampuan gereja untuk mengabarkan Injil melalui melalui budaya sebagai jembatannya. Perubahan hanya terdapat dalam metode atau cara tetapi pesannya akan tetap sama yaitu Yesus yang mati dan bangkit. Teladan Yesus yang masuk dalam konteks manusia adalah gambaran tentang cara Allah untuk menyelamatkan manusia. Gerakan misioner yang menyesuaikan dengan konteks memiliki fokus pelayanan dan sifatnya bersahabat. Dunia dipandang sebagai ladang pelayanan yang luas di mana kabar baik tersebut akan ditaburkan dan siap tumbuh. Kontekstualisasi menjadi motivasi pelayanan yang sensitif terhadap suatu kebutuhan, perubahan-perubahan radikal dan budaya. Jadi gerakan misi yang dilakukan dengan cara-cara sesuai konteks masyarakat yang dilayani disebut sebagau gerakan misi kontekstual.

Gerakan misi kontekstual juga akan menolong terjadinya pertumbuhan dan pelipatgandaan gereja di tengah masyarakat yang majemuk. Yang sering terjadi adalah penolakan Injil bukan disebabkan oleh menolak salib tetapi karena memaksa mereka untuk melepaskan budaya dan menjadi orang yang terasing dari komunitas mereka sendiri. Oleh sebab itu gerakan misi ini harus terus melakukan "creatives approach" agar tujuan misi itu tercapai. Gerakan ini merupakan inti kehidupan suatu gereja

${ }^{19}$ Makmur Halim, Gereja di Tengah-tengah Perubahan Dunia (Malang: Gandum Mas,2011), 28 
sehingga gereja tersebut akan dapat memobilisasi seluruh jemaat sehingga gereja itu akan sehat dan bertumbuh dengan pesat ketika semua berfungsi dengan normal. Menurut Yohanes Marsono dalam artikelnya menyatakan:

"Gereja mengemban misi Kristus sehingga setiap kata-kata dan tindakan gereja harus dilakukan demi kebaikan semua umat manusia mulai dari proses penyelamatan, menyembuhkan, membebaskan dan menolong sesama manusia." 20

Gerakan misi kontekstual memusatkan perhatian kepada jiwa atau orang bukan lagi gedung yang utama karena semangat mereka adalah membawa sebanyak-banyaknya orang datang kepada Kristus. Kontekstualisasi merupakan suatu metode pendekatan yang paling efektif bagi gereja-gereja di Indonesia karena Indonesia sangat multi kultur dan beragam persoalan dalam dimensi yang beragam. ${ }^{21}$

Menurut Daniel Trihandarkha dalam artikel jurnal SIAP mengatakan:

"Christians in the early days were regarded as quiet, non violent, worshipers of imageless God. They were also known as gracious community and fear no death people. These made them distinct from Jews who had enormous influence in their theology." 22

Maksud tulisan tersebut adalah orang Kristen dapat menunjukkan perbedaan dari orang pada umumnya karena mereka dikenal sebagai orang yang tenang, tidak menyukai kekerasan, dan menyembah Tuhan dengan tulus hati. Mereka dikenal sebagai orang yang baik dan tidak takut mati. Kualitas ini menjadikan mereka unik dan berkualitas. Sehingga ketika orang Kristen bersaksi kepada orang lain, berita Injil disampaikan bukan hanya melalui kata-kata tapi juga lewat karakter dan cara menghayati hidup yang bergantung kepada Tuhan.

Orang Kristen perlu meneladani cara Tuhan Yesus masuk dalam kehidupan manusia dengan pengajarannya yang penuh kuasa dan mukjizat. Artinya gereja memposisikan diri bukan sebagai pihak yang paling benar sendiri, tetapi mengajak yang lain untuk bersama-sama menemukan kebenaran itu dan berjalan dalam terang kebenaran tersebut. Jika hal itu

\footnotetext{
${ }^{20}$ Yohanes Marsono, "Misi Gereja dalam Penegakan Hak Asasi Manusia” Jurnal STULOS Volume 3 no.2, 2004; 91

${ }^{21}$ Makmur Halim, 63

${ }^{22}$ Daniel Trihandarkha, “The Historical 'Early Church”, Jurnal SIAP Vol.7, No.2. 2018; 34
} 
terjadi maka kualitas iman dan kerohanian mereka akan berdampak dengan nyata kepada masyarakat tanpa memandang jenis agamanya. Yesus juga mengajarkan kepada murid-murid-Nya untuk tidak pernah takut menghadapi dunia dan para penguasa jika memang mereka berjalan dalam kebenaran itu.

\section{Kesimpulan}

Berdasar pembahasan di atas dapat disimpulkan bahwa gereja mulamula dapat bertumbuh dan berkembang karena adanya gerakan missioner yang dilakukan oleh umat Tuhan tanpa kecuali. Semua jemaat Tuhan memiliki kewajiban yang sama untuk mewartakan Injil tanpa harus memikirkan siapa yang menjadi pendetanya atau misionarisnya. Hubungan yang dekat dengan Tuhan Yesus sebagaimana hubungan antara murid Yesus dengan Maria ibu Yesus menunjukkan bahwa kegiatan bermisi adalah diikat dalam hubungan kekeluargaan yang kuat atas dasar kasih. Kasih kepada Kristus membuat setiap orang akan memberitakan kesaksian tentang Yesus dengan penuh sukacita. Gerakan missioner ini akan berdampak kepada misi Allah untuk menyelamatkan dunia. Amanat Agung Tuhan Yesus ditujukan kepada semua orang percaya agar Injil diberitakan ke seluruh penjuru bumi. Gereja yang melakukan gerakan ini akan menjadi gereja yang hidup karena terus bergerak dan aktif dalam gerakan Allah.

Situasi dan aturan-aturan yang dirasakan sebagai diskriminatif atau mempersulit gerakan justru dijadikan sebagai pemicu dan pemacu gerakan missioner ini. Tujuannya bukan untuk memenangkan sebuah kompetisi tetapi untuk menjalankan tugas Missio Dei. Gereja diutus untuk bergerak keluar dengan misi ilahi yaitu Kerajaan Allah terjadi di dalam dunia ini sebagaimana dikehendaki Allah. Gereja tidak lagi sekedar sebagai kerajaankerajaan kecil dalam dunia tetapi bersatu untuk memuliakan nama-Nya.

Sejarah pertumbuhan jemaat mula-mula menunjukkan bahwa Tuhan turut bekerja bersama para rasul dengan pertolongan Roh Kudus sehingga banyak jiwa bertobat dan datang kepada Kristus. Perubahan konteks dan masa mengakibatkan gereja mengalami pergeseran dalam memaknai misi. Berbagai aliran atau denominasi bermunculan dengan alasan masing-masing. Namun apapun argumentasinya, gereja tersebut akan bertumbuh ketika mereka berani menyampaikan Injil kepada orang lain. Ukuran keberhasilan yang dipakai bukan seberapa banyak yang didapat, tetapi seberapa banyak 
melakukan kegiatan misi. Ada kalanya situasi yang sulit bagi kekristenan justru memicu ledakan pertumbuhan jemaat, karena mereka menjadi lebih bergantung kepada Tuhan dalam kesulitannya. Pergeseran pola pemerintahan gereja juga menjadi salah satu ciri bahwa gereja itu bersifat dinamis dan adaptable.

Kesimpulan terakhirnya adalah gereja pada masa kini perlu mengobarkan kembali spirit misionernya dalam kemasan baru yang menyesuaikan dengan konteks saat ini. Model penginjilan perlu dilakukan secara kontekstual. Pemuridan diperlukan bagi para petobat baru agar mereka memperoleh bimbingan dalam pertumbuhan imannya yang masih baru. Selain itu, gereja masa kini seharusnya memiliki motivasi yang benar di dalam menjalankan misi. Pewartaan Injil bukan sekedar dengan tujuan menambah data keanggotaan gereja tetapi didorong oleh kasih atau empati kepada orang-orang yang belum percaya kepada Yesus.

\section{Kepustakaan}

Aritonang, Jan., Berbagai Aliran di Dalam dan di Sekitar Gereja. Jakarta: BPK. Gunung Mulia, 2012.

Amaladoss, Michael., Mission in Asia: A Reflection on Ecclesia in Asia. New York: Orbis Books, 2012.

Batlajery, Agustinus M., "Konteks yang Mempengaruhi Eklesiologi Calvin". Waskita: Jurnal Studi Agama dan Masyarakat. Vol. 2, No. 1. 2014.

Bauer, F.,W. Danker, A., Greek English Lexicon of the New Testament and other Early Christian Literature, third ed., Chicago:University of Chicago Press, 2000.

Boland, B J., Van Niftrik., Dogmatika Masa Kini. Jakarta: BPK. Gunung Mulia, 2015.

Crosby, Michael H., Apakah Engkau Mengasihi Aku? Jakarta: BPK Gunung Mulia, 2000.

De Jong, Kees., "Misiologi dari Perspektif Teologi Kontekstual”, Jurnal Gema Teologi, sac.ukdw.ac.id., 2007.

Halim, Makmur., Gereja di Tengah-tengah Perubahan Dunia. Malang: Gandum Mas, 2011.

Lawrence, Paul., The IVP Concise Atlas of Bible History. Illinois: Inter Varsity Press, 2004. 
Marsono,Yohanes., "Misi Gereja dalam Penegakan Hak Asasi Manusia", Jurnal STULOS. Volume 3 No. 2, 2004.

Petersen, Jim., Church Without Walls. Jakarta: Pioner Jaya, 2012.

Schaff, P., History of the Christian Church in The Middle Ages. Grand Rapids: Eerdmans Publishing Company, 1949.

Shaw, Ian J., Christianity the Biography. London: Inter Varsity Press, 2016.

Shipman, Mike., Kepemimpinan Kerasulan. Bandung: Dian Cipta, 2017.

Susanto, Hery., "Penemuan Jati Diri Gereja Jemaat Kristus pada Abad yang Baru”, Jurnal SIAP Vol.5 No.1, 2016.

Trihandarkha, Daniel., "The Historical 'Early Church", Jurnal SIAP Vol.7, No.2, 2018.

Vun, William., Who is Building Whose Church?, Jakarta: Nafiri Gabriel, 2010.

Woi Bule,Yosep Aurelius., "Revolusi Mental dengan Membangun Karakter Cinta Pluralitas". Atma Reksa, Jurnal Pastoral dan Kateketik, jurnal. stiparende ac.id., 2017. 